

\title{
SURVEILLANCE OF CITRUS CANKER IN PESHAWAR DIVISION AND ITS MANAGEMENT THROUGH HOST RESISTANCE
}

\author{
Basharat Mehmood, Muhammad Tariq-Khan, Hafiz Matee-ur-Rehman, Muhammad T. Younas \\ Department of Plant Pathology, Faculty of Agriculture, University of The Poonch Rawalakot, Pakistan
}

\begin{abstract}
A B S T R A C T
The present study was conducted to record incidence and severity of citrus canker and to screen citrus species against this disease. A detailed survey was conducted in 19 nurseries and 13 commercial orchards of Peshawar division during 2011. It was observed that almost all the nurseries were severely affected by the disease. The highest disease incidence $(100 \%)$ and severity (31.54\%) were observed in New Tarnab nursery in (Mention name of district here). Among the orchards, Shado II showed comparatively more disease severity (2.92\%) as compared to other orchards. Bacteria, isolated from symptomatic plant samples on nutrient agar medium produced small, shiny yellow colonies with smooth margins. Biochemical tests further confirmed the bacteria as Xanthomonas axonopodis pv. citri. Detached and attached leaf assays were made to check the resistance of four citrus species i.e. Citrus sinensis (sweet orange), C. aurantifola (kaghazi lemon), C. paradise (Grape fruit) and C. medica (Lime). C. medica was moderately resistant whereas $C$. sinensis was found to be the most susceptible against the disease. Present study will be useful for developing best possible solution for the management of citrus canker in Peshawar division.
\end{abstract}

Keywords: Xanthomonas axonopodis pv. citri, host resistance, citrus canker, incidence

\section{INTRODUCTION}

Citrus is one of the most important fruits grown in the different cot of the world including Pakistan. It is the main source of vitamin C, Ligar and some amino acids (Sahi et al,, 2007). On the national scale citrus occupies an area of 199.9 thousand ha with a total production of 2132.2 thousand tons, whereas in Khyber Pakhtunkhwa, it occupies an area of 4.2 thousand ha with a total production of 33.8 thousand tons (MINFAL, 2009). The average yield of citrus in KPK is very low. One of the reasons for this low yield is the prevalence of different diseases such as citrus greening, gummosis, citrus tristeza virus, citrus decline and citrus canker etc. Among these bacterial diseases, citrus canker is of considerable importance causing severe losses to citrus orchards and nurseries and reducing the market value of citrus fruits by producing canker spots. $X$.

Submitted: May 05,2019

Revised: May 25, 2019

Accepted for Publication: June 25, 2019

* Corresponding Author:

Email: rajabasharat@upr.edu.pk

(C) 2019 Pak. J. Phytopathol. All rights reserved. axonopodis pv. citri (Xac) is reported to be the causal agent of bacterial citrus canker. This pathogen is the potential threats to citrus trees, influencing all forms of important citrus grown throughout the world. The bacterium has various pathovars and variants which cause three different forms of franker (Vauteria et al., 1995). Geographical distribution and host range is the basis of differentiating these three forms (Stall and Seymour, 1983). The form of canker which is present in Asia which is caused by $X$. axonopodis pv. citri is the most wide-spread and causes the most destructive form of the disease. Controversy still exists on the geographical origin of citrus canker, but it is thought to have originated from south-east Asia or India and occurs in more than 30 countries throughout the world (Berger, 1914; Civerolo, 1985; Verniere et al., 1998). In Indo-Pak sub-continent, this disease is more common (Arif et al., 1962). In the citrus growing areas of Punjab, this disease is more common than those of other provinces in the country (Sahi et al., 2007). X.axonopodis pv. citri is Gram negative, rod shaped bacterium, with single polar flagellum, its growth is obligate aerobe with maximum temperature for growth around $35-39^{\circ} \mathrm{C}$ and the optimum temperature 
is $28-30{ }^{\circ} \mathrm{C}$ (Sahi et al., 2007). The bacterium infects all above ground parts of susceptible hosts, particularly young, actively growing leaves, twigs, stems, trunks, thorns, and fruit. Infection of young leaves and twigs usually occurs within 10-21 days after shoots begin to develop. On leaves, the disease manifests as oily looking, circular spots, mostly on the upper surface of leaves. On sterns, pustule mad, coalesce to split the epidermis along the stem length, and occasionally girdling of young sterns may occur. Older lesions on leaves and fruit tend to have more elevated margins and are at times surrounded by a yellow chlorotic halo and a sunken center. These are especially noticeable on fruits, but lesions do not enter and affect the inner quality of fruit. Tissue Hyperplasia is the main diagnostic tool symptom of this disease an essential diagnostic symptom of the disease (Gabriel et al., 2000). The occurrence of lesions is seasonal coinciding with periods of heavy rainfall, high temperature and growth factor.

Xac is rod shaped having size 1.5-2.0 x 0.5-0.75 mm, Gramnegative and has a polar flagellum. Growth is obligatory aerobic. Colonies on culture media are usually yellow as a result of Xanthomonadin pigment production. When glucose or other sugars are added to the culture medium, colonies become very mucoid due to the production of extracellular polysaccharide slime. The optimum temperature range for growth is 28 to $30^{\circ} \mathrm{C}$, and the maximum temperature range for growth is 35 to $39^{\circ} \mathrm{C}$. The bacterium is negative for methyl red test, nitrate decline and indole manufacture (Chand and Pal, 1982; Goto,1992).

As far as research work on bacterial diseases of citrus in Khyber Pakhtunkhwa (KPK) is concerned, absolutely nothing has been done so far. Keeping in view the importance of citrus production in KPK, Pakistan, detailed studies were conducted on this disease.

\section{MATERIALS AND METHODS}

Survey and sampling: A detailed survey was conducted in major citrus-growing areas and commercial citrus nurseries of Peshawar division to record the incidence and severity of citrus collected during the surveys. A total of thirteen orchards and nineteen nurseries at symptoms were canker. In order to isolate the pathogen, symptomatic plant leaves from different locations were collected. At each location, two commercial citrus orchards were randomly selected where five randomly chosen trees were assessed for disease severity.

Disease severity: Disease severity was calculated in each orchard and nursery by using the following modified 0-3 disease rating scale (Wri-ht et al., 2005): where

$0=$ No lesions on leaf;

$1=$ Less than $50 \%$ of leaf area covered by lesions;

$2=50 \%$ or more of leaf area covered by lesions;

3 = Leaf completely covered by lesions and severely necrotic.

Different values of the scale were averaged together (i.e. $\mathrm{En} / \mathrm{N}$ ) to determine the absolute disease severity value (e.g. smaller values) or analyzed by Bdliya and Dahiru, (2006) statistical equation.

$$
\mathrm{S}=\mathrm{I} 00 \mathrm{En} / 3 \mathrm{~N}
$$

Where $\mathrm{S}=$ citrus canker severity (\%).

En = summation of individual ratings.

$\mathrm{N}=$ total number of leaves observed.

3 = highest score on the severity scale.

Disease incidence: For determining disease incidence in an orchard, 10 trees randomly selected and observed for disease symptoms while in nurseries all the plants were observed. Disease incidence was calculated simply by dividing the number of trees showing disease symptoms over total number of trees observed and multiplied by one hundred.

$$
\text { Disease incidence }=\frac{\text { No. of diseased trees }}{\text { No. of Total trees Observed }} \times 100
$$

Isolation and purification of the pathogen: A lesion or a small portion of a fresh lesion on a leaf was excised with the help of a sterilized razor blade and placed in sterilized phosphate buffered saline (PBS) 1, adjust to pH 7.4 with conc. HCL to make the volume 1 litre and later shaken in a rotary shaker for $20 \mathrm{~min}$ at room temperature. The supernatant was centrifuged for 20 $\mathrm{min}$ at $10000 \mathrm{rpm}$ and the pellet was re-suspended in 1 $\mathrm{ml}$ PBS. An aliquot of $50 \mathrm{ul}$ of the bacterial suspension was used on nutrient agar (NA) medium for direct isolation. The NA medium $(25 \mathrm{~g}$ readymade nutrient agar per litre) prepared was sterilized at $121{ }^{\circ} \mathrm{C}$ for 20 minutes, cooled to $56{ }^{\circ} \mathrm{C}$ for the addition of antibiotic cephalexin $(16 \mathrm{mg} / \mathrm{L})$ shaken well and then poured in sterilized Petri plates under aseptic conditions. Three plates were used for each isolate which was then incubated at 27 to $30{ }^{\circ} \mathrm{C}$ for $72 \mathrm{~h}$. Observations were made for light yellow, small, round and raised bacterial colonies. Selected colonies were sub-cultured on NA to obtain a pure culture.

\section{Identification of the pathogen}

Gram staining: On a clean glass slide a thinly air dehydrated bacterial film with a light flame was fixed. With $0.5 \%$ aqueous crystal violet, the specimen was treated for 30 seconds and later for one minute washed 
with water. For one minute, the specimen was dipped in Iodine, washed with water and after that $95 \%$ ethanol was added for depolarization. The specimen was again washed with water and for approximately 10 seconds counter-stained with safranin. Eventually, the specimen was rinsed with water then dried. At 10 and $40 \mathrm{x}$ magnifications, the specimen was observed microscopically. Gram positive bacteria preserve purple to blue black color of crystal violet dye and gramnegative bacteria discolor red (Gerhardt, 1981).

Potassium hydroxide test: Potassium hydroxide test was performed to confirm the Gram staining results. The bacterial culture was detached from Petri plates by using sterilized toothpick under aseptic condition and placed that bacterial culture on a clean sterilized slide is adding few drops of $3 \% \mathrm{KOH}$ solution and stirred for 10 seconds by the fast circular motion of hand (Ryu, 1940).

Starch hydrolysis test: In starch hydrolysis test, 28g NA powdered was dissolved in water under constant heating. $2 \mathrm{~g}$ starch was dissolved in $10 \mathrm{ml}$ distil water and add NA into the water with constant stirring. $100 \mathrm{ml}$ of this basic nature medium was dispensed in a flask and autoclaved it for $10 \mathrm{~min}$ at $115{ }^{\circ} \mathrm{C}$ temperature and then, poured in Petri dish. Isolates were transferred under aseptic condition and for seven days incubate it at $27{ }^{\circ} \mathrm{C}$. After that plates were filled with Lugol's Iodine (Cowan, 1974).

Tween 80 hydrolysis test: $15 \mathrm{~g}$ agar, $5 \mathrm{~g} \mathrm{NaCl}, 10 \mathrm{~g}$ peptone and $0.1 \mathrm{~g} \mathrm{CaC1}{ }_{2} .2 \mathrm{H}_{2} \mathrm{O}$ were dissolved in litre distilled water for preparation of basal medium which was used in this test. The $\mathrm{pH}$ of the medium was adjusted to 7.22 to 7.4 and autoclaved at $121{ }^{\circ} \mathrm{C}$ for 15 min to obtain the final concentration (1\%) Tween 80 was added. The medium was poured in Petri dishes, inoculation of bacteria was done by streaking method and after that these plates were incubated for seven days at $27^{\circ} \mathrm{C}$ (Sierra, 1957).

Anaerobic growth test: $0.3 \mathrm{~g} \mathrm{KH}_{2} \mathrm{PO}_{4}, 2 \mathrm{~g}$ peptone, $0.3 \mathrm{~g}$ agar, $5 \mathrm{~g} \mathrm{NaCl}$ and $3 \mathrm{~g}$ Bromothymol blue were dissolved in 1litredistilled water and maintain $\mathrm{pH}$ to 7.1. Into each test tube, 5 nil of this medium was poured and autoclaved for 20 min at $121^{\circ} \mathrm{C}$. In each tube that contains the medium, an aliquot of $0.5 \mathrm{ml}$ of sterile $10 \%$ glucose suspension was added under aseptic condition. For the test of isolate two test tubes were inoculated. $5 \mathrm{~m} 1$ of sterile melted paraffin was dropped in one test tube and the tube was incubated at $27^{\circ} \mathrm{C}$ (Hugh and Leifson, 1953).

Screening for host resistance: A total of four commercial citrus species i.e. C. sinensis, C. aurantifola, C. paradise and $C$. media were screened to find resistance, against the three isolates of citrus canker bacterium. Both in-vitro and in-vivo leaf assay were used for this purpose.

Detached leaf assay: Detached leaves of the four species, C. sinensis, C. aurantifola, C. paradise and C. media were surface-sterilized in $70 \%$ ethanol for 1 minute, rinsed in sterilized distilled water and aseptically placed on the surface of $1 \%$ water-agar plates in such a way that the upper shiny face of the leaf touched the water-agar surface. Two triangular cut-wounds (one on each side of the mid-vein) were made with the help of a sterilized razor blade and about $20 \mathrm{ul}$ of bacterial suspension (in $0.85 \%$ saline having $\left(10^{6}-10^{8} \mathrm{cfu} / \mathrm{ml}\right)$ was placed in each wound. Control leaves were similarly wounded but $20 \mathrm{ul}$ of $0.85 \%$ saline solution having no bacteria were placed in their wounds. Leaves were incubated at $25{ }^{\circ} \mathrm{C} \pm 3$ for $7-14$ days. Leaves were observed for the development of symptoms (lesions with a raised margin having a slightly chlorotic region in the center) (Broadbent et al., 1992). Completely randomized design (CRD) was used for the experiment with three replications and five leaves per replication per treatment. Data were recorded by measuring the size $(\mathrm{mm})$ of the individual lesions at 7 th and 13th day of inoculation.

Attached leaf assay: Potted plants of the four-citrus species, C. sinensis, C. aurantifola, C. paradise and $C$. medica were used for attached leaf assay. The lower sides of citrus leaves of four varieties were pin-pricked and then infiltrated with $0.85 \%$ suspension $\left(10^{6}\right.$ $10^{8} \mathrm{cfu} / \mathrm{ml}$ ) of the bacterial isolates with the help of needle less syringes. Inoculation was done on two sites per leaf, one on each side of mid-vein (Broadbent et al., 1992). The water-soaked area was marked with a permanent marker and the inoculated plants were placed in a screen house for 7-14 days. Control leaves were similarly infiltrated with the saline suspension only. Completely randomized design (CRD) was used for the experiment with three replications and five leaves per replication per treatment. Data were recorded by measuring the size $(\mathrm{mm})$ of the individual lesions at 7 th and 8th day of inoculation.

Statistical analysis: Data collected were analyzed in CRD by analysis of variance. LSD test was also carried out to test the significant difference among the means of different treatments Steel and Torrie, 1980).

\section{RESULTS}

Disease incidence: The results of the server for recording citrus canker incidence and severity in 
nurseries and orchards of the Peshawar division arc presented in Table 1 and Table 2. A total of 19 nurseries were surveyed which showed disease incidence ranging from 0 to $100 \%$. Plants in the green leaf nursery showed no indication of disease. However, the plants from Lalazar, Peshawar Garden, Gul Khyber, Green Acre and Green Wave nurseries showed disease incidence that ranged from 50 to $80 \%$. Plants in all other nurseries showed disease incidence of $100 \%$. Thirteen orchards were also surveyed (Table 2) in Peshawar division for determining disease incidence. There was a great difference in disease incidence of different orchards. The orchards at Sora Khail, Latif Bacha and Kaka sahib I showed $0 \%$ disease incidence. Conversely, disease incidence in other orchards ranged from 20 to $40 \%$. Maximum disease incidence (40\%) was recorded at Shado I, Watar I and Kaka sahib III orchards while minimum (20\%) was observed for Sora Khail I, Rasoo I, Khai I and Kaka Sahb II.

Table 1. Incidence and severity of citrus canker in citrus nurseries of Peshawar division.

\begin{tabular}{llcc}
\hline District & Location & Incidence $\%$ & Severity \% \\
\hline Nowshera & Rasheed nursery, Taro Jaba & 100 & 17.4 \\
& Green wave nursery Taro Jaba80 & 80 & 10.5 \\
& Khyber nursery Taro Jaba & 100 & 21.34 \\
& Maliar nursery Taro Jaba & 100 & 24.47 \\
& Green wave nursery Taro Jaba & 100 & 17.53 \\
\hline Peshawar & Naz garden Hayatabad & 100 & 19.51 \\
& Green acre Hayatabad & 80 & 11.33 \\
& Spring rose garden Havatabad & 100 & 23.56 \\
& Tarnab nursery Hayatabad & 100 & 29.50 \\
& New TarnabHavatabad & 100 & 31.54 \\
& Green leaf Hayatabad & 0 & 5.66 \\
& Lalazar nursery Hayatabad & 0 & 19.76 \\
& Greenhouse Hayatabad & 50 & 5.55 \\
& Peshawar garden Hayatabad & 100 & 25.64 \\
& Madina nursery Hayatabad & 70 & 16.67 \\
& Paracha nursery Hayatabad & 100 & 21.54 \\
& I.S garden Hayatabad & 100 & 20.12 \\
& Gul Khyber Hayatabad & 100 & 27.43 \\
\hline
\end{tabular}

Table 2. Incidence and severity of citrus canker in commercial citrus orchards of Peshawar.

\begin{tabular}{llccl}
\hline & Location & Incidence & Severity & Remarks \\
\cline { 2 - 4 } & Shado I & 40 & 2.32 & Leaf miner, citrus greening \\
& Shado II & 30 & 2.92 & Fruit rot, leaf miner \\
& Sora khail I & 20 & 0.96 & Leaf miner \\
& Sora khail II & 0 & 0 & Leaf miner \\
& Watar I & 40 & 0.24 & Sever citrus greening \\
& Watar II & 30 & 1.30 & Sever citrus greening \\
& Rasool khail I & 20 & 0.64 & Leaf miner, Severe citrus greening \\
& Rasool khail II & 30 & 1 & Leaf miner, Severe citrus greening \\
& Latif bacha I & 0 & 0 & Fruit rot, leaf miner, scale insect \\
& Kaka sahb 1 & 0 & 0 & Citrus greening \\
& Kaka sahb 11 & 20 & 2.20 & Citrus greening, leaf miner \\
& Kaka sahb III & 40 & 1.5 & Citrus greening, leaf miner \\
\hline District Peshawar & Malakandher & 20 & 0.84 & Citrus greening, leaf miner \\
\hline
\end{tabular}


Disease severity: Citrus canker severity was recorded from different nurseries and orchards in and around Peshawar Division. Citrus plants at Green Leaf nursery showed no disease. However, plants from all other nurseries exhibited varying disease severity ranging from 5.55 to $31.54 \%$. Plants at Peshawar Garden and Lalazar nursery were similar in case of disease severity and presented minimal values of 5.55 and 5.66, respectively. On the other hand, plants in New Tarnab showed the highest degree of disease severity (31.54\%). Citrus plants of various nurseries including Green Wave, Rasheed, Green Acre, Green House and Paracha showed disease severity in the range of 10 to 20\%. Plants of Khyber, Maliar, Spring Rose, Tarnab, Madina, 1.S Garden, Gul Khyber and Green Midows nurseries ranged from 20 to $30 \%$ in disease severity. The results for disease severity among different orchards are presented in Table 3. The degree of disease severity ranged from 0.96 to 2.92. Plants of Latif Bacha1, Kaka sahb I and Sora Khali ll orchards showed complete resistance against the disease.

Table 3. Characterization of Xac isolate obtained from $C$. sinensis host.

\begin{tabular}{lccccc}
\hline Isolate & Gram staining & $3 \% \mathrm{KOH}$ & Starch hydrolysis & Tween 80 Hydrolysis & Anaerobic Growth \\
\hline Malakandher11 & - & - & + & + & - \\
Hayatabad 11 & - & - & + & + & - \\
Tarnab 11 & - & - & + & + & - \\
\hline
\end{tabular}

Identification of the bacterium: Plates incubated with the infected samples were checked for the presence of $X$. axonopodis pv. citri and characteristic yellow colonies of the causal agent were observed. On nutrient agar, medium isolated colonies were mucoid, shiny in texture and small round. The results showed about Gram staining pathogen was Gram negative bacterium when counter discolored with Safranin that produces a red color. For further confirmation, the $\mathrm{KOH}$ test was carried out for gram staining results and the test was negative. A thread like a slime was produced by the isolates when detained with a toothpick. By the production of clear zones after 7 days, $X$. axonopodis pv. citri hydrolyses starch incubate which is manifested when cultures were discolored with Lugol's Iodine. Around the colonies, tween 80 test showed that dense zones were observable. Anaerobic growth test readily differentiates aerobic from anaerobic bacteria. Anaerobic activity occurs when the blue color of the medium replaced by yellow color. Any isolate that failed to modify the color was interpreted as aerobic.

Detached leaf assay: The isolates were tested for their ability to cause disease against different citrus species. The isolates were applied to detached leaf under laboratory condition and results \% were taken at 7 and 13 days after inoculation (Table 4). Size of the lesion increased quickly after inoculation till the seventh day. However, from seventh to the thirteenth day, onward there was little increase in lesion size. The isolates behaved differently in causing lesions to citrus species. Similarly, species showed differential response to isolates inoculation. Among isolates, Malakandher 11,
Hayatabad11 and Tarnab 11 caused greater lesions in $C$. aurantifola, $C$. sinensis, $C$. medica and $C$. paradise the size of the lesions was $8.23,8.00 .9 .77$ and $8.17 \mathrm{~mm}$ at the seventh day which was increased to $11.17,11.60,11.33$ and $9.83 \mathrm{~mm}$ on the thirteenth day. On the basis of mean values when calculated among species, isolate Tarnab 11 was found to cause a greater lesion. Similarly, among species, $C$. sinensis appeared to be more susceptible to citrus canker and developed larger lesion than all other species The C. aurantifola, C. paradise and C. medica behaved almost similarly to tested isolates and developed more or less same size lesions at the seventh day. The size of the lesion increased when again measured at the thirteenth day. The maximum increase was found in $C$. aurantifola where lesion increased from 6.00 to $11.77 \mathrm{~mm}$. On the basis of means, it was concluded that the isolate from Tarnab 11 caused maximum lesion while among species $C$. sinensis appeared to be more susceptible towards citrus canker when inoculated with different isolates.

Attached leaf assay: All the isolates were also tested against different citrus species under field conditions on leaves attached to the plants. The results are presented in Table 5. A difference observed between attached and detached leaf assay was that there is more increase in lesion size in attached leaves when compared with detached leaves after 13 days of inoculation. The isolate and citrus species showed different responses in terms of lesion formation when tested against each other. The isolates Malakandher 11, Hayatabad 11 and Tarnab 11 caused greater lesions in C. sinensis, C. aurantifola and C. paradise. 
Table 4. The response of citrus germ-plasm to citrus canker isolates using detached leaf assay.

\begin{tabular}{|c|c|c|c|c|c|c|c|c|c|c|}
\hline \multirow{3}{*}{ Isolates } & \multicolumn{5}{|c|}{ Size of the lesion (mm) } & \multicolumn{5}{|c|}{ Size of the lesion $(\mathrm{mm})$} \\
\hline & \multicolumn{5}{|c|}{07 days } & \multicolumn{5}{|c|}{13 days } \\
\hline & C. sinensis & C. aurantifola & C. paradise & C. medica & Mean & C. sinensis & C. aurantifola & C. paradise & C. medica & Mean \\
\hline Malakandher 11 & 7.50 & 8.23 & 6.0 & 6.0 & $6.93 c$ & 8.57 & 6.5 & 11.17 & 8.17 & $8.6 c$ \\
\hline Hayatabad 11 & 8.00 & 7.5 & 7.83 & 8.67 & $7.50 \mathrm{~b}$ & 11.6 & 8.93 & 9.0 & 8.33 & $9.42 \mathrm{~b}$ \\
\hline Tarnab 11 & 9.77 & 6 & 8.33 & 8.17 & $8.10 \mathrm{a}$ & 11.3 & 11.7 & 10.33 & 9.83 & $10.81 \mathrm{a}$ \\
\hline Control & 0 & 0 & 0 & 0 & $0 \mathrm{~d}$ & 0 & 0 & 0 & 0 & $0 \mathrm{~d}$ \\
\hline Mean & $6.31 \mathrm{a}$ & $5.43 b$ & $5.54 \mathrm{~b}$ & $5.25 b$ & & $7.87 a$ & $6.80 \mathrm{~b}$ & $7.62 \mathrm{a}$ & $6.54 \mathrm{~b}$ & \\
\hline LSD & \multicolumn{5}{|c|}{$\begin{array}{l}\text { Isolates }(\mathrm{I})=0.4215 \\
\text { Varieties }(\mathrm{V})=0.4215 \\
\mathrm{I} \times \mathrm{V}=1.445\end{array}$} & \multicolumn{5}{|c|}{$\begin{array}{l}\text { Isolates }(\mathrm{I})=0.7022 \\
\text { Varieties }(\mathrm{V})=0.7022 \\
\mathrm{I} \times \mathrm{V}=1.4045\end{array}$} \\
\hline
\end{tabular}

Mean followed by the same letters in the column/row do not differ from each other at $0.05 \%$ significance level.

Table 5. The response of citrus germ-plasm to citrus canker isolates using attached leaf assay.

\begin{tabular}{|c|c|c|c|c|c|c|c|c|c|c|}
\hline \multirow{3}{*}{ Isolates } & \multicolumn{5}{|c|}{ Size of the lesion (mm) } & \multicolumn{5}{|c|}{ Size of the lesion (mm) } \\
\hline & \multicolumn{5}{|c|}{07 days } & \multicolumn{5}{|c|}{13 days } \\
\hline & C. sinensis & C. aurantifola & C. paradise & C. medica & Mean & C. sinensis & C. aurantifola & C. paradise & C. medica & Mean \\
\hline Malakandher 11 & 4.87 & 2.77 & 4.77 & 3.07 & $3.86 \mathrm{~b}$ & 7.5 & 7.5 & 10 & 7.5 & $7.91 \mathrm{a}$ \\
\hline Hayatabad 11 & 4.83 & 2.97 & 6.3 & 2.5 & $4.15 \mathrm{ab}$ & 8.33 & 8.33 & 7.5 & 6.67 & $7.70 \mathrm{a}$ \\
\hline Tarnab 11 & 5.3 & 6.8 & 3.5 & 2.5 & $4.54 \mathrm{a}$ & 10 & 6.67 & 7.5 & 6.67 & $7.91 \mathrm{a}$ \\
\hline Control & 0 & 0 & 0 & 0 & $0.00 \mathrm{c}$ & 0 & 0 & 0 & 0 & $0.00 \mathrm{~b}$ \\
\hline Mean & $3.75 a$ & $3.13 \mathrm{~b}$ & $3.65 a$ & $2.01 \mathrm{c}$ & & $6.45 a$ & $5.62 \mathrm{~b}$ & $6.25 a$ & $5.20 \mathrm{~b}$ & \\
\hline LSD & \multicolumn{5}{|c|}{$\begin{array}{l}\text { Isolates }(I)=0.4840 \\
\text { Varieties }(V)=0.4840 \\
I \times V=0.9680\end{array}$} & \multicolumn{5}{|c|}{$\begin{array}{l}\text { Isolates }(\mathrm{I})=0.8487 \\
\text { Varieties }(\mathrm{V})=0.8487 \\
\mathrm{I} \times \mathrm{V}=0.9680\end{array}$} \\
\hline
\end{tabular}

Mean followed by the same letters in the column/row do not differ from each other at a $0.05 \%$ significance level.

The sizes of the lesions were 4.87, 6.80 and 6.30 $\mathrm{mm}$ respectively. The size of the lesion caused by Hayatabad 11 in $C$. aurantifola was increased from $2.97 \mathrm{~mm}$ at seventh day to $8.33 \mathrm{~mm}$ after thirteenth day. The $C$. medica was the only species among all species which showed maximum resistance to lesion formation among all isolates. On the basis of mean values at seventh day, isolate from Tarnab 11 caused greater lesion size than other isolates.

\section{DISCUSSION}

The aim of the present study was to determine the $\%$ disease incidence and severity of citrus canker in commercial citrus orchards nurseries of Peshawar division. For this purpose, a detailed survey of commercial citrus orchards of Peshawar division, especially those of Manki Sharif and Zairat Kaka Sahib was carried out in 2011. Moreover, different citrus nurseries of Peshawar division were also visited for the purpose of documenting the disease incidence and severity.

The study included 13 orchards and 19 nurseries. Most of the nurseries had $100 \%$ disease incidence; some nurseries were, however, free of 
disease. On the other hand, orchards had a very low disease incidence. Likewise, disease severity was also comparatively higher (31.54) in nurseries than in commercial orchards. These results were in line with the work done by Sahi et al. (2007) Gambley et al. (2009). There could be several reasons to explain the low disease incidence and disease severity in commercial orchards as compared to that in nurseries. The initial inoculum plays an important role in establishing the disease in an area. If disease-free plants are selected for starting a citrus orchard, there would probably be no disease in the orchard later on. It is quite possible that the orchards of Manki Sharif and Zairat Kaka Sahib were started with disease-free material. The long-distance spread of the disease, like many other diseases, is believed to occur via diseased plant material (Schubert et al., 2001). Moreover, these areas, having mountainous, terraces are physically separated from other areas which makes it more difficult for disease to get there through natural agents such as rainwater, splashing rains and insects etc.

It is also possible that the citrus variety used in the citrus orchards of the above-mentioned areas is relatively more resistant to the disease as compared to other varieties. Most of the orchards were planted with sweet orange which is reportedly (Gottwald et al., 2002) more resistant than lime, lemon, and grapefruit. Some of the reasons for varietal resistance could be the chemical nature of the variety, the less abundance of stomata (used by the citrus canker bacterium to enter plant tissue), occurrence of more stomata on lower surface of leaves (less chance of water film to stay on lower surface , and resistance to wound-causing insects especially leaf miner which is considered to be responsible for local spread of the disease (Schubert et al., 2001). Broadbent et al. (1992) reviled that citrus leaves having abundant leaf miner channels had more severe citrus canker symptoms. Sanitation and better management of the orchard could be another reason that might explain the low disease incidence in the commercial orchards visited compared to most of the nurseries. Sources of primary inoculum are lesions on shoots, leaves, branches and fruits of citrus and citrus relatives, infected plant debris on/in soil, weeds, and soil. However, bacteria surviving in lesions only on citrus and citrus relatives are known to be of primary epidemiological significance (EPPO/CABI, 1992). Therefore, removal of significant inoculum sources by pruning infected shoots and defoliation of affected trees, control of leaf miners and timely application of copper sprays (Serizawa et al., 1985) could result in the protection of citrus plants from the disease. Most of the orchards which were either free of the disease or had less disease were well-managed. Similarly, citrus nurseries which were free of disease were better-managed. Weather conditions especially humidity and temperature are also important for disease development. Successful establishment and spread of citrus canker occur when the virulent pathogen, free water, and susceptible citrus tissue are present; the spread is enhanced by the wind of at least $8 \mathrm{~m} / \mathrm{s}$ (Gambley et al., 2009). Sothiosorubini et al. (1986) found that the ideal conditions for citrus canker were $30{ }^{\circ} \mathrm{C}$ and $100 \%$ relative humidity. The relatively lower temperature of Manki Sharif and Zairat Kaka Sahib might have contributed to the lower incidence of the disease in those orchards. The mountainous terrain of these areas might reduce wind speed, thus making it more difficult for the wind-based spread of the disease resulting in lower disease incidence. Xanthomonas are produce mucous, smooth, yellow colonies on NA medium. Such colonies were consistently isolated on NA medium. Alot of tests were carried out in order to characterize the pathogen on a biochemical basis. The bacteria isolated were gram-negative on the basis of the Gram reaction and $\mathrm{KOH}$ test. Starch hydrolysis test was positive for the bacteria. Tween 80 hydrolysis test was positive while anaerobic growth test was negative for the bacteria. The results of attached and detached leaf assays indicated that all of the four tested species of citrus including $C$. sinensis, C. medica and C. paradise were susceptible to citrus canker. Among these species, $C$. sinensis was the most susceptible while $C$. medica showed some resistance against citrus canker. These findings were in line with OPEIT/EPPO Bulletin 35 (2005) and Sun et al. (2008). Among the isolates, Tarnab 11 produced bigger lesions. This suggests that there is some pathogenic variation among different involving isolates of citrus canker bacterium. However, a detailed study on the pathogenic and genetic variability of the pathogen needs to be conducted. This will provide valuable information for citrus germplasm screening.

\section{REFERENCES}

Arif, A. G., M. Akhtar and M. Ibrahim. 1962. Citrus diseases and their control. Punjab Fruit J., 26: 369-70.

Bdliya, B. S. and B. Dahiru. 2006. Efficacy of some plant extracts on the control of potato tuber soft rot caused by Erwinia carotovora ssp. carotovora. Journal of Plant Protection Research, 46: 285-294. 
Berger, E. W. 1914. Citrus canker: History of citrus canker in Florida. Agric. Exp. Sta. Bull., 124: 27-30.

Broadbent. P., Fahy, P. C., Gillings, M. R., Bradley, J. K., and Barnes, D. 1992. Asiatic citrus canker detected in a pummelo orchard in northern Australia. Plant Disease., 76: 824-829.

Chand, J. N. and V. Pal, 1982. Citrus canker in India and its management. In: Problems of citrus diseases in India (S.P. Raychaudhuri \& Y.S Ahlawat, Eds.). Surabhi Printers and Publishers, New Delhi. pp. 21-26.

Civerolo, E. L. 1985. Indigenous Plasmids in X. campestris pv. citri. Phytopathology. 75: 524-528.

Cowan, S. T. 1974. Manual Col the identification of Medical bacteria. Cambridge University Press, Great liritain. 2:38 pp.

EPPO/CAB1. 1992. Xanthomonas campestris pv. citri. In: Quarantine pests for Europe. Smith, I. M.; McNamara, D. G.; Scott, P. R.; Harris, K. M. (Eds.). CAB International, Wallingford, UK.

Gabriel. D. W., Y. P. Duane and C. Ramadugu. 2000. The molecular mechanism of citrus canker pathogenicity and a gene engineering approach to control. Mtn. Soc. Citriculture Cong., Dec. 3-7, Orlando. Florida (Abst.), p. 51.

Gambley, C. F., A. K. Miles, M. Ramsden, V. Doogan, V. Thomas, J. E. Parmenter and P. J. L. Whittle. 2009. The distribution and spread of citrus canker in Emerald, Australia. Auatralian Plant Pathology, 38: 547-557.

Gerhardt. P. 1981. Manual of Methods of General Bacteriology. American Society of Microbiology Washington, D. C. 180-212.

Goto, M. 1992. Citrus canker. In: Plant diseases of international importance. Vol. III. J. Kumar, H. S. Chaube, U. S. Singh \& A. N. Mukhopadhyay (Eds.) Prentice- Hall, Englewood Cliff, NJ. pp. 170-208.

Gottwald, T. R, J. H. Graham and T. S. Schubert. 2002. Citrus canker the pathogen and its impact. Online. Plant health process. Doi:10.1094/P11P-2002-0812-01-RV. http://plantmnegementnetiwork.orb/pub/phb/revie w/citruscanker/.

Hugh, R. and E. Leifson. 1953. The taxonomic significance of fermentative versus oxidative metabolism of carbohydrates of various Gram-bacteria Journal of bacteriology, 66:24-26.

MINFA. 2009. Agricultural statistics of Pakistan. Govt. of Pakistan. Ministry of food-Agri. Livestock, Food Agriculture and livestock, Division (Economic wing) Islamabad. 45-46.
Ryu, E. 1940. A simple method of differentiation between Gram-positive and Gram-negative organisms without staining. Kitasato Archives of Experimental Medicine, 17:58-63

Sahi, T. S., M. Usman, M. Alzal, A. Rashed and A. Habib. 2007. Pak. J. Bot., 39(4): 1319-1327.

Schubert., T. S., S. A. Rizvi, X. Sun, T. R. Gottwald, J. H. Graham and W. N. Dixon. 2001. Meeting the challenge of eradicating citrus canker in Florida-Again. Plant Disease., 85: 340-356.

Serizawa, S. Inoue, K. Suzuki, M. 1985. Studies on citrus canker disease. IX. Seasonal changes in disease development and correct timing of bactericidal application. Bulletin of the Shizuoka Perfectural Citrus Experiment Station No. 21, 35-43.

Sierra, G. 1957. A simple method for the detection of lipolytic activity of microorganisms and some observations on the influence of the contact between cells and fatty substances. Antonie Van Leeuwenhoek., 23: 15-22

Sothiosorubini, N., R. S. Sundersan and A. Sivapalan, 1986. Studies on Xanthomonas campestris pv citri, causing canker disease of citrus disease of citrus. Vingnanam J. of science, 68(2):82-86.

Stall. R. E. and C. P. Seymour. 1983. Canker, a threat to citrus in the Gulf- Coast States. Plant Dis., 67: 581-585.

Steel, R. G. D. and J. H. Torrie. (1980). Principal and procedures of statistics McGraw Hill Book Co. New York (2nd Edition) P: 633.

Sun, L.-C., L. V. Mackey, J. Luo, J. A. Fuselier and D. H. Coy. 2008. Targeted chemotherapy using a cytotoxic somatostatin conjugate to inhibit tumor growth and metastasis in nude mice. Clinical medicine. Oncology, 2: CMO. S970.

Vauterin, L., B. Hoste, K. Kersters and J. Swings, 1995. Reclassification of Xanthomonas. Mtn.Intenational Journal of systematic Bacteriology,45: 472-489.

Verniere, C., J. S. Hartung, O. P. Pruvost, E. L. Clverolo, A. M. Alvarez, P. Maestri and J. Luisetti, 1998. Characterization of phenotipical distinct strains Xanthomonas axonopodis pv. citri from Southwest Asia. European Journal of Plant Pathology, 104: 477487.

Wright,.P. J., clark, G. E and J. Koolaard. 2005. Control of bacterial soft rot of calla (Zantedeschia spp.) by pathogen exclusion, elimination and removed. New Zealand Journal of Crop and Horticultural Sciences. 33: 117-123. 